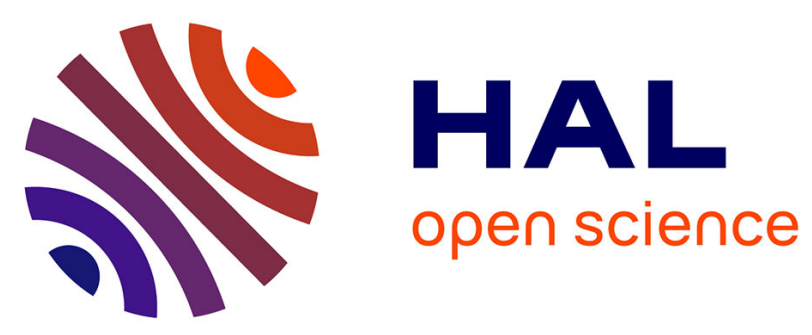

\title{
Towards an Improved Inventory of N2O Emissions Using Land Cover Maps Derived from Optical Remote Sensing Images
}

Rémy Fieuzal, Claire Marais-Sicre, Tiphaine Tallec

\section{- To cite this version:}

Rémy Fieuzal, Claire Marais-Sicre, Tiphaine Tallec. Towards an Improved Inventory of N2O Emissions Using Land Cover Maps Derived from Optical Remote Sensing Images. Atmosphere, 2020, 11 (11), pp.1188. 10.3390/atmos11111188 . hal-03251580

\author{
HAL Id: hal-03251580 \\ https://hal.inrae.fr/hal-03251580
}

Submitted on 7 Jun 2021

HAL is a multi-disciplinary open access archive for the deposit and dissemination of scientific research documents, whether they are published or not. The documents may come from teaching and research institutions in France or abroad, or from public or private research centers.
L'archive ouverte pluridisciplinaire HAL, est destinée au dépôt et à la diffusion de documents scientifiques de niveau recherche, publiés ou non, émanant des établissements d'enseignement et de recherche français ou étrangers, des laboratoires publics ou privés. 
Article

\title{
Towards an Improved Inventory of $\mathrm{N}_{2} \mathrm{O}$ Emissions Using Land Cover Maps Derived from Optical Remote Sensing Images
}

\author{
Rémy Fieuzal *, Claire Marais Sicre and Tiphaine Tallec $\mathbb{B}$ \\ Centre d'Études Spatiales de la BIOsphère (CESBIO), Université de Toulouse, CNES/CNRS/INRAE/IRD/UPS, \\ 31000 Toulouse, France; claire.marais-sicre@cesbio.cnes.fr (C.M.S.); tiphaine.tallec@cesbio.cnes.fr (T.T.) \\ * Correspondence: remy.fieuzal@cesbio.cnes.fr; Tel.: +33-561556484
}

Received: 5 October 2020; Accepted: 28 October 2020; Published: 3 November 2020

\begin{abstract}
Agricultural soils are the primary anthropogenic source of $\mathrm{N}_{2} \mathrm{O}$ emissions, one of the most important greenhouse gases, because of the use of nitrogen $(\mathrm{N})$ fertilizers. The proposed method provides access to an inventory of potential $\mathrm{N}_{2} \mathrm{O}$ emissions (the term potential refers to possible but not yet actual) at a fine scale, with an annual update, without a heavy deployment linked to a collection of field measurements. The processing chain is applied to optical satellite images regularly acquired at a high spatial resolution during the 2006-2015 period, allowing a better spatial and temporal resolution of the estimates of potential $\mathrm{N}_{2} \mathrm{O}$ emissions from crops. The yearly potential $\mathrm{N}_{2} \mathrm{O}$ emissions inventory is estimated over a study site located in southwestern France, considering seven main seasonal crops (i.e., wheat, barley, rapeseed, corn, sunflower, sorghum and soybean). The first step of the study, that is the land use classification, is associated with accurate performances, with an overall accuracy superior to 0.81 . Over the study area, the yearly potential budget of $\mathrm{N}_{2} \mathrm{O}$ emissions ranges from 97 to 113 tons, with an estimated relative error of less than $5.5 \%$. Wheat, the main cultivated crop, is associated with the maximum cumulative emissions regardless of the considered year (with at least $48 \%$ of annual emissions), while maize, the third crop regarding to the allocated area (grown on less than $8 \%$ of the study site), has the second highest cumulative emissions. Finally, the analysis of a 10-year map of the potential $\mathrm{N}_{2} \mathrm{O}$ budget shows that the mainly observed crop rotation (i.e., alternating of wheat and sunflower) reaches potential emissions close to $16 \mathrm{~kg} \mathrm{~N}_{2} \mathrm{O}$ emitted per hectare, while the monoculture maize is associated with the maximum value (close to $28.9 \mathrm{~kg}$ per hectare).
\end{abstract}

Keywords: $\mathrm{N}_{2} \mathrm{O}$ emissions; classification; random forest; optical images

\section{Introduction}

Recent global agreements on greenhouse gas emission reductions have reinforced the need to provide more informed national greenhouse gases inventories. Nitrous oxide $\left(\mathrm{N}_{2} \mathrm{O}\right)$ emissions contributed substantially to the overall radiative forces [1]. As one of the most important sectors in global anthropogenic nitrous oxide emissions (more than 60\%), agriculture constitutes an important place in anthropogenic GHG emissions [2]. The $\mathrm{N}_{2} \mathrm{O}$ is mainly released from cultivated soils, because of increased inputs of $\mathrm{N}$ fertilizers, animal wastes and biological $\mathrm{N}$ fixation. Improving our ability to quantify and map agricultural $\mathrm{N}_{2} \mathrm{O}$ fluxes on agricultural regional scales may help in proposing mitigation strategies and assessing their efficiency.

The bottom-up approach provides emission inventories summed from field measurement or model results. Intergovernmental Panel on Climate Change (IPCC) developed a protocol [3] in such a way and proposed the use of emission factors, derived from numerous literatures, adapted for each 
emission sector (agriculture, transportation, industry, etc.). Although that methodology is seriously criticized for agriculture sector inventory [4], it requires few variables, including the use of regional statistics (land occupation, $\mathrm{N}$ fertilizer input, etc.), and allows for inventorying potential yearly $\mathrm{N}_{2} \mathrm{O}$ emissions on the national scale in an easy way [5]. The top-down approach is based on atmospheric measurements (from space and airborne remote sensing, static and local tall tower) combined with the inversion model [6,7]. The latter methodology presents the advantage to give an integrative global $\mathrm{N}_{2} \mathrm{O}$ budget estimation which, inversely to the bottom-up approach, is not subjected to the potential high spatial $\mathrm{N}_{2} \mathrm{O}$ flux variability, depending on the soil occupation. However, while public policies aimed at promoting mitigation strategies and the use of lower GHG emitting practices, the top-down approach, which not takes into account the land mosaics, is definitely not adapted, especially to discriminate natural from anthropogenic $\mathrm{N}_{2} \mathrm{O}$ emissions [2]. Moreover, both methodologies do not take into account the spatial distribution of land cover, and thus do not allow for analyzing the spatial pattern of potential hotspots of $\mathrm{N}_{2} \mathrm{O}$ emissions at a fine scale [8]. Thus, they are not scheduled to reliably detect potential emissions on individual field scale, and where mitigation efforts could be targeted in recommending alternative options of agricultural practices (such as choice of crop rotation) to farmers.

To fix the problem, some studies proposed more complex bottom-up approaches with the use of process-based models (Daycent, LandscapeDNDC) accounting for land occupation mapping and influence of environmental drivers [8-12]. However, this more sophisticated methodology requests numerous parameters and variables that may be difficult to address at larger scale than the field. Besides, those inventories are based on the use of regional statistical census data that may generate high uncertainties in $\mathrm{N}_{2} \mathrm{O}$ inventories.

In such a context, remote sensing technology is expected to provide spatially explicit information of soil occupation in time. Remote sensing analysis provides more accurate crop covering data than the census data, which are often inadequate or problematic. The land use classifications derived from remote sensing images constitute, then, valuable information, allowing for mapping the potential yearly $\mathrm{N}_{2} \mathrm{O}$ emissions at a fine spatial scale, consistent with fragmented agricultural landscapes. This study aims at taking advantage of multi-temporal optical images regularly acquired during the 2006-2015 period, to propose a simple methodology to estimate potential yearly emissions of $\mathrm{N}_{2} \mathrm{O}$ through classification maps. The paper first presents a description of the study site together with an overview of the characteristics of in situ and satellite data. The processing steps used to map the potential yearly emissions of $\mathrm{N}_{2} \mathrm{O}$ are presented in Section 3. The results section is divided into two parts, the performances of land use classification obtained during ten successive agricultural seasons are first addressed, and such information then allows for the mapping of potential emissions of $\mathrm{N}_{2} \mathrm{O}$ and the associated errors of the main crops cultivated in Southwestern France. Finally, the limitations of the proposed methodology and prospects are given in Section 4.

\section{Experiments}

\subsection{Study Area}

The study area is part of a French observatory, named Regional Spatial Observatory South-West (OSR SW). The OSR SW is part of the regional Zone Atelier Pyrénées Garonne (ZA PYGAR) and the national Research Infrastructure Critical Zone Observatories: Research and Applications (OZCAR) [13], which are all devoted to monitoring and evaluating the natural and anthropogenic determinants of ecosystems functioning (in terms of biogeochemical cycles) at a regional catchment scale and its landscape. It is located in southwestern France near Toulouse (Figure 1), a $1275 \mathrm{~km}^{2}$ footprint area centered on the coordinates $43^{\circ} 2^{\prime} 9.5273^{\prime \prime} \mathrm{N}, 1^{\circ} 2^{\prime} 41.9482^{\prime \prime} \mathrm{E}$. The region is governed by a temperate climate with Mediterranean influences, with an annual rainfall of approximately $600 \mathrm{~mm}$ and mean daily air temperature ranging from a few degrees in winter to $25^{\circ} \mathrm{C}$ in summer. The eastern part of the site is quite flat (from 144 to $381 \mathrm{~m}$, mean altitude $238.6 \mathrm{~m}$ ), with slopes lower than $1^{\circ}$, in contrast 
to the western part, where the slopes are at a mean of $4.5^{\circ}$. The soils are mainly dominated by silt $(47 \%)$, followed by clay $(29.7 \%)$ and sand $(23.3 \%)$, indexed by three classes of the European Soil Map (HYPRES) texture classification system (i.e., Fine, Medium and Medium Fine). Agricultural activity occupies $90 \%$ of the landscape, with surfaces dedicated to crops, grasslands, forests, urban areas, and water bodies [14]. The study area is characterized by a seasonality regarding the growing season of crops, which are grouped into two broad classes; namely, summer and winter crops, depending on their period of cultivation.

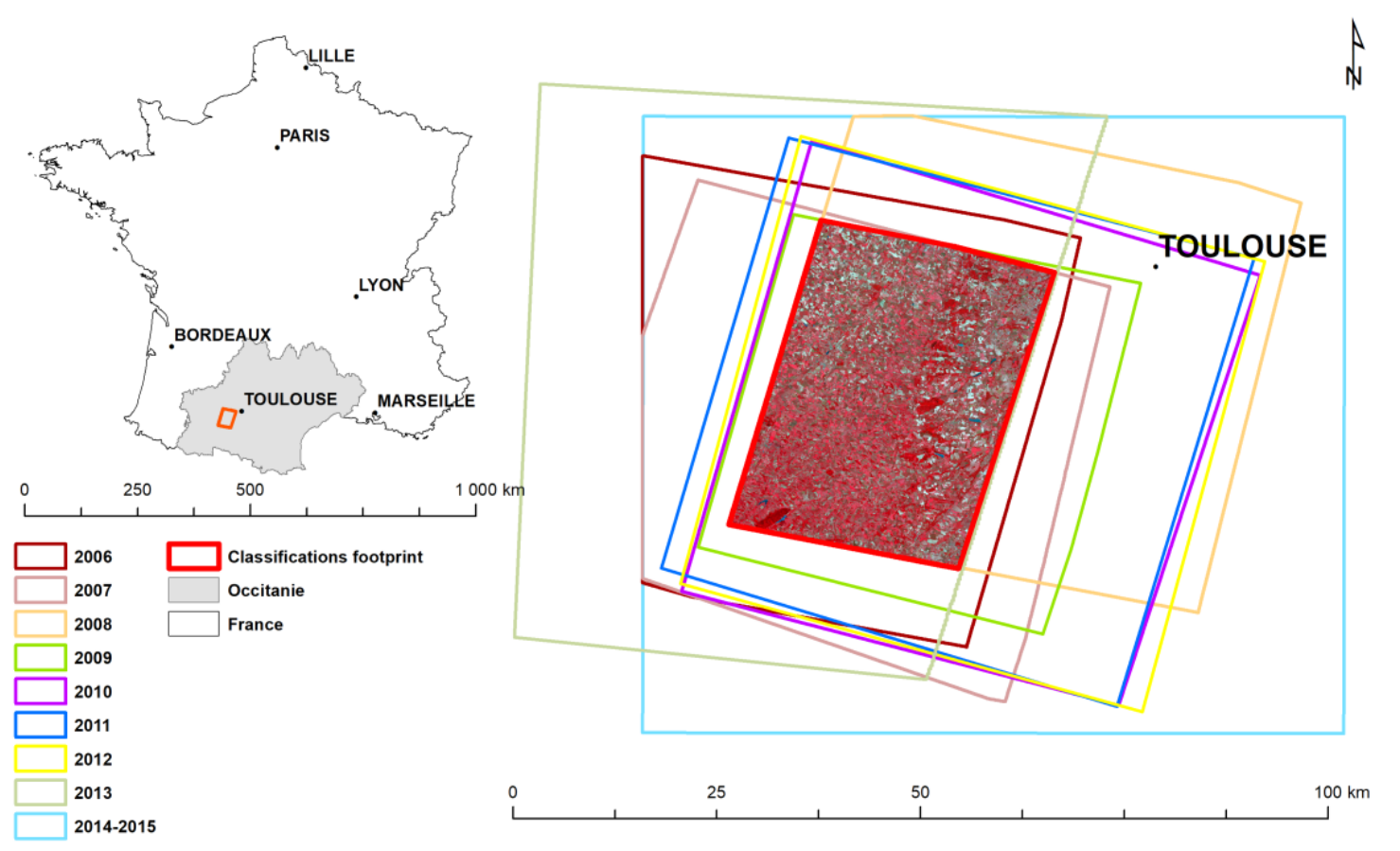

Figure 1. Location overview of the study site in southwestern France, together with the yearly and common footprint area, superimposed on a color-composed image acquired by Spot (14 June 2012).

\subsection{In Situ Data-Registre Parcellaire Graphique (RPG)}

The RPG is a geographic information system that displays detailed information on land use and land holding structures, declared by the French farmers to obtain subsidies from European administrative bodies. The information is supplied for agricultural surfaces (comprising 28 land-use classes) that cover one or more adjacent plots of different crops belonging to the same farmer. On average, $68 \%$ of these surfaces are made up of a single plot. The samples used to train and validate the classification are selected among these plots, retaining an average of 10,000 pixels each year, distributed according to the representativeness of the classes on the study site.

\subsection{Satellite Data}

Time series of high spatial resolution satellite acquisitions were constituted in the optical domain (Figure 2). During the 2006-2015 period, the satellite acquisitions were performed by Spot-2/4/5 and Landsat-8, using multispectral mode. The images were acquired with at least three narrow wavelengths (green, red and near-infrared) and with a spatial resolution ranging from 10 to $30 \mathrm{~m}$. An amount of 126 images were acquired throughout the decade, with a number of acquisitions per year ranging from 5 to 24 images, for 2006 and 2014/2015, respectively. 


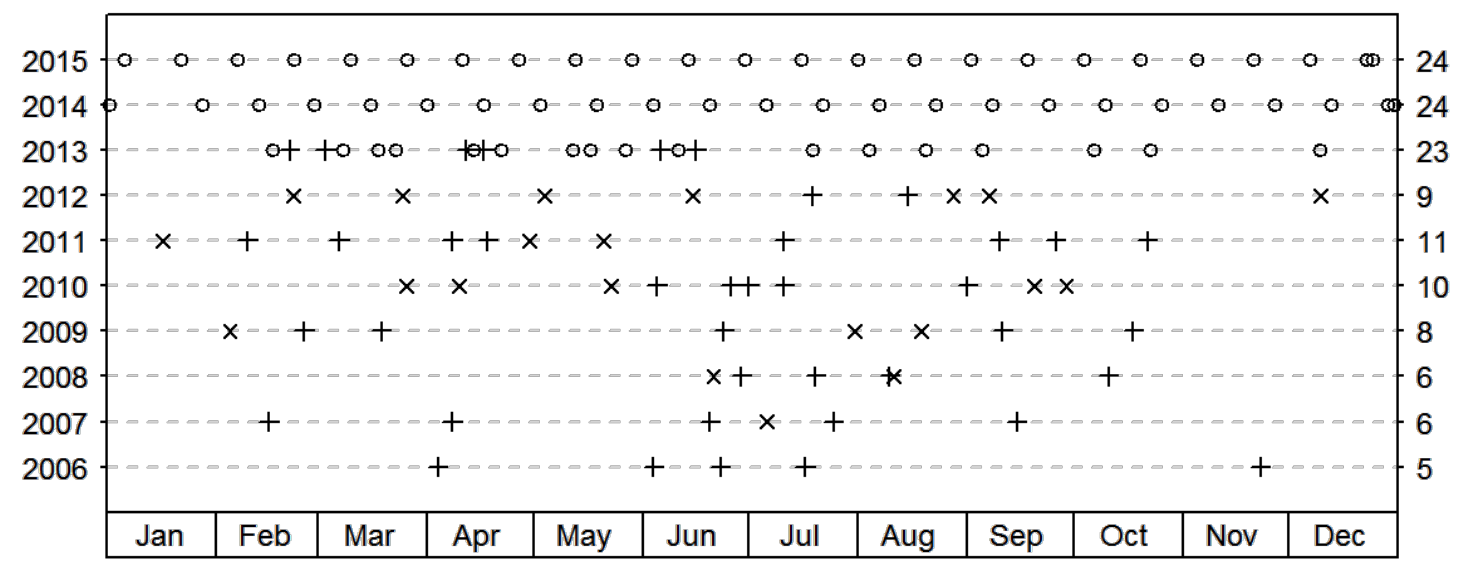

Figure 2. Timeline of the optical satellite acquisitions performed by Spot-2/4/5 or Landsat- 8 during the 2006-2015 period. The total number of images acquired per year is indicated on the right, and different symbols to represent resolutions of $10 \mathrm{~m}(\times), 20 \mathrm{~m}(+)$ and $30 \mathrm{~m}(\mathrm{o})$.

\subsubsection{Spot Data}

Spot-2, Spot-4 and Spot-5 are European satellites that were launched in January 1990, March 1998 and in May 2002, respectively [15]. These satellites have optical instruments that operate in at least in three different spectral bands, that are green, red and near-infrared wavelengths for Spot-2 $(0.545$, 0.645 and $0.835 \mu \mathrm{m}$, respectively). In addition, the two most recent satellites provide signals acquired in medium-infrared wavelengths $(1.665 \mu \mathrm{m})$. The images were acquired using the multispectral mode, at a spatial resolution of 10 or $20 \mathrm{~m}$, depending on the considered satellite and spectral band.

\subsubsection{Landsat-8 Data}

Landsat-8 is an American satellite that was launched in February 2013 [16]. This satellite carries the operational land imager and the thermal infrared sensor which operate in spectral bands ranging from the visible to the thermal wavelengths. The images consist of one panchromatic band characterized by a spatial resolution of $10 \mathrm{~m}$, two thermal bands collected at $100 \mathrm{~m}$, and 8 bands with a spatial resolution of $30 \mathrm{~m}(0.440,0.480,0.560,0.655,0.865,1.370,1.610$ and $2.200 \mu \mathrm{m})$.

\subsubsection{Processing of Optical Images}

All the images were acquired with constant geometric properties (avoiding the effect of bidirectional reflectance distribution function) and were ortho-rectified using CNES ortho-rectification tools. The detection of clouds and their shadows on the soil and the correction of atmospheric disturbances (i.e., aerosol effects) were based on the multi-temporal algorithm developed by [17], which is based on the assumption that surface reflectance and aerosol optical properties vary differently according to time and location.

\subsection{Methodology}

The proposed sequence of steps for estimating potential $\mathrm{N}_{2} \mathrm{O}$ emissions is illustrated in Figure 3 . After the pre-processing step, the multi-temporal reflectances acquired throughout the agricultural season are used to produce annual land use classification at the initial image resolution. The algorithm and the main processing steps are described in Section 2.4.1. Once the classifications are produced, the spatial resolution is harmonized with pixels of the same size of 20 by $20 \mathrm{~m}$. The yearly maps of $\mathrm{N}_{2} \mathrm{O}$ are finally estimated through an inventory approach (emission factor is provided together with values of mineral nitrogen inputs in Section 2.4.2), while the confusion matrix is used as a basis for calculating an error on the yearly budget of $\mathrm{N}_{2} \mathrm{O}$ emissions (procedure described in Section 2.4.3). 


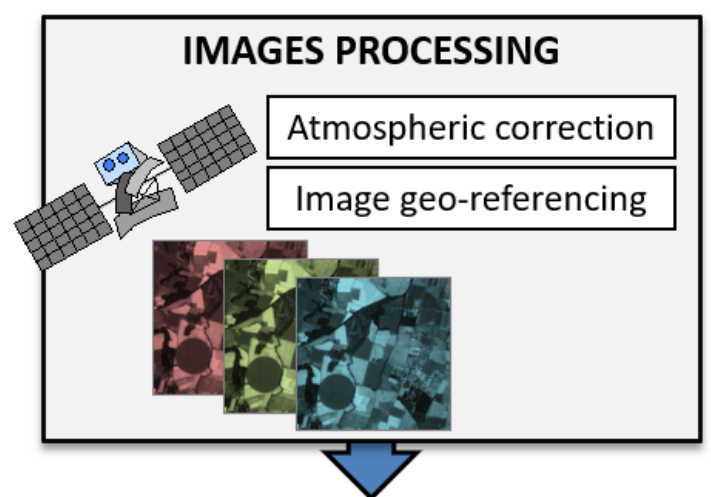

MULTI-TEMPORAL REFLECTANCES

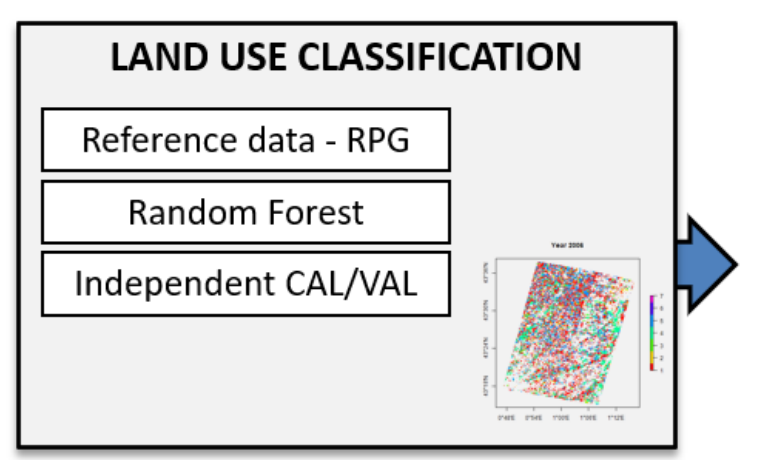

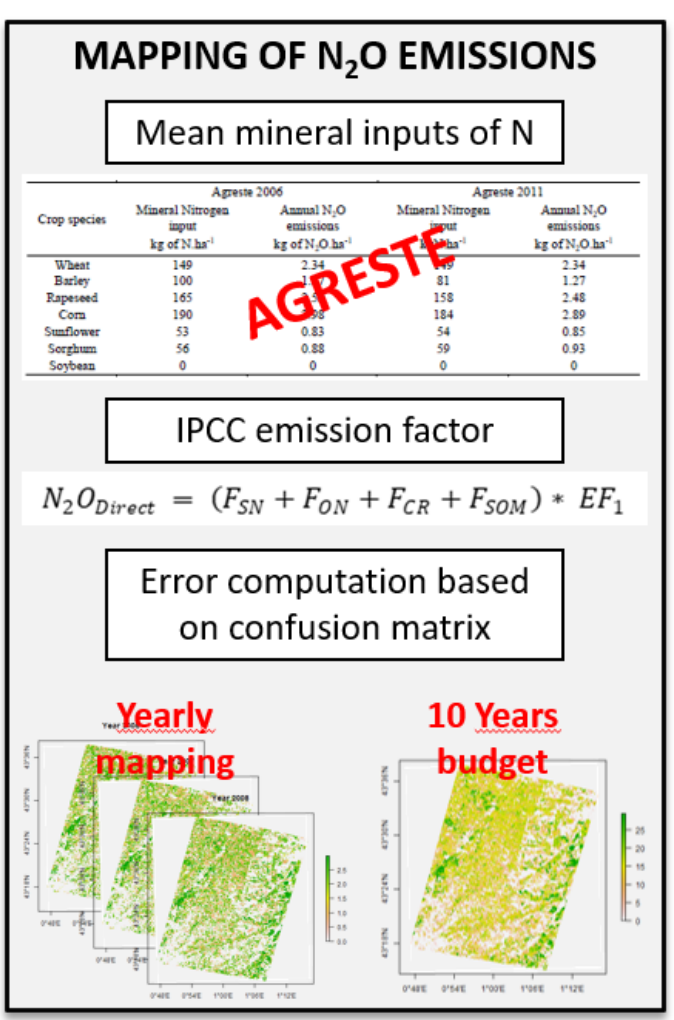

Figure 3. Synopsis of the successive steps involved to estimate potential emissions of $\mathrm{N}_{2} \mathrm{O}$.

\subsubsection{Land Use Classification}

Every year, the multi-temporal reflectances constituted the input variable of a Random Forest (RF) implemented in the Orfeo ToolBox [18]. Such a classifier has been widely used in different fields, offering satisfactory performances when combined with remote sensing images $[19,20]$. The statistical approach presents several advantages-a reduced over fitting, a low influence of noise on the data, and a high stability of the results - which mainly come out of the bootstrap aggregating procedure (also called bagging). An ensemble of independent trees is constructed on a subset of bootstrap samples derived from the original dataset and aggregated through means of a majority vote, in the cases of classification.

The training and validation steps are performed on independent subsets of samples containing $50 \%$ of the data. The robustness of the approach of classification is tested by repeating the learning and validation phases 10 times on different randomly selected subsets of samples. For the sake of conciseness, the results presented hereinafter only focus on one case-performance obtained on the different subsets being stable without any bias.

The validation of the land use classification maps is performed by deriving several classical indices from the confusion matrix. The numbers of correctly and incorrectly classified pixels are combined to compute the rates of true positives (i.e., the rate of well-classified pixels), false positives (i.e., the rate of reference pixels wrongly placed in other classes) and false negatives (i.e., the rate of pixels placed in one class but belonging to another). For each considered crop class, those parameters are combined to derive the precision (i.e., percentage of pixels coming from the reference class that were assigned to the right group), the recall (i.e., percentage of correctly classified pixels with respect to the total number of pixels in the class) and the F-score (i.e., harmonic average of the precision and recall [21,22]). This latter score has the advantage of increasing when the precision and recall are close and high, and of decreasing strongly when one of the parameters is low. Finally, two metrics are retained to estimate the overall accuracy of the yearly land use classification maps; that is, the kappa (i.e., relative difference 
between the proportion of agreement observed and the proportion of random agreement) and the overall accuracy (i.e., ratio of correctly classified elements to total number of elements examined).

\subsubsection{Mapping of $\mathrm{N}_{2} \mathrm{O}$ Emissions}

The IPCC Tier 1 approach ([3], Equation (1)) was partially applied for each year and for each crop class at pixel spatial scale.

$$
\mathrm{N}_{2} \mathrm{O}_{\text {Direct }}=\left(\mathrm{F}_{\mathrm{SN}}+\mathrm{F}_{\mathrm{ON}}+\mathrm{F}_{\mathrm{CR}}+\mathrm{F}_{\mathrm{SOM}}\right) \times \mathrm{EF}
$$

where:

$\mathrm{N}_{2} \mathrm{O}_{\text {Direct }}=$ annual direct $\mathrm{N}_{2} \mathrm{O}$ emissions produced from managed soils, $\mathrm{kg} \mathrm{N}_{2} \mathrm{O}$ year ${ }^{-1}$;

$\mathrm{F}_{\mathrm{SN}}=$ annual amount of synthetic fertilizer $\mathrm{N}$ applied to soils, $\mathrm{kg} \mathrm{N}$ year $^{-1}$;

$\mathrm{F}_{\mathrm{ON}}=$ annual amount of animal manure, compost, sewage sludge and other organic $\mathrm{N}$ additions applied to soils, $\mathrm{kg} \mathrm{N}$ year $^{-1}$;

$\mathrm{F}_{\mathrm{CR}}=$ annual amount of $\mathrm{N}$ in crop residues (above-ground and below-ground), returned to soils, $\mathrm{kg} \mathrm{N}_{\text {year }}{ }^{-1}$;

$\mathrm{F}_{\mathrm{SOM}}=$ annual amount of $\mathrm{N}$ in mineral soils that is mineralized, $\mathrm{kg} \mathrm{N}_{\text {year }}{ }^{-1}$;

$E F=$ emission factor for $\mathrm{N}_{2} \mathrm{O}$ emissions from $\mathrm{N}$ inputs, $\mathrm{kg} \mathrm{N}_{2} \mathrm{O}$ (kg N input) ${ }^{-1}$.

A default value for $\mathrm{EF}$ was used and set at $1.57 \%$ (with a range uncertainty of $0.471-4.71 \%$ ) $\mathrm{N}_{2} \mathrm{O}$ emitted from the annual amount of synthetic fertilizer $\mathrm{N}\left(F_{S N}\right)$ applied only, the other $\mathrm{N}$ input not being available at this time for our study scale. The mean annual values of mineral $\mathrm{N}$ applied per crop species were referenced by the French ministry of agriculture and food for two investigation campaigns conducted in 2006 and 2011 (Table 1, [23]). Only a few variations in mineral inputs were observed between the two investigation campaigns (maximal difference was observed for barley). The mineral nitrogen input depends on the considered crop; wheat, rapeseed and corn showing the highest values (ranged from 149 to $190 \mathrm{~kg} \mathrm{~N}$ per hectare). At the opposite side, soybean is grown without the input of mineral nitrogen.

Table 1. Average of the mineral nitrogen input and of the associated potential $\mathrm{N}_{2} \mathrm{O}$ emissions per crop type, for the two available investigations conducted in 2006 and 2011, by the French ministry of agriculture and food.

\begin{tabular}{|c|c|c|c|c|}
\hline \multirow{3}{*}{ Crop Species } & \multicolumn{2}{|c|}{ Agreste 2006} & \multicolumn{2}{|c|}{ Agreste 2011} \\
\hline & $\begin{array}{c}\text { Mineral } \\
\text { Nitrogen Input }\end{array}$ & $\begin{array}{c}\text { Annual } \mathrm{N}_{2} \mathrm{O} \\
\text { Emissions }\end{array}$ & $\begin{array}{c}\text { Mineral } \\
\text { Nitrogen Input }\end{array}$ & $\begin{array}{c}\text { Annual } \mathrm{N}_{2} \mathrm{O} \\
\text { Emissions }\end{array}$ \\
\hline & kg of N.ha ${ }^{-1}$ & kg of $\mathrm{N}_{2} \mathrm{O} \cdot \mathrm{ha}^{-1}$ & kgN.ha ${ }^{-1}$ & kg of $\mathrm{N}_{2} \mathrm{O} \mathrm{ha}^{-1}$ \\
\hline Wheat & 149 & 2.34 & 149 & 2.34 \\
\hline Barley & 100 & 1.57 & 81 & 1.27 \\
\hline Rapeseed & 165 & 2.59 & 158 & 2.48 \\
\hline Corn & 190 & 2.98 & 184 & 2.89 \\
\hline Sunflower & 53 & 0.83 & 54 & 0.85 \\
\hline Sorghum & 56 & 0.88 & 59 & 0.93 \\
\hline Soybean & 0 & 0 & 0 & 0 \\
\hline
\end{tabular}

The yearly maps of $\mathrm{N}_{2} \mathrm{O}$ emissions were computed considering two periods from 2006 to 2010 and from 2011 to 2015, using, respectively, the mineral nitrogen input observed during the investigation conducted in 2006 and 2011. Finally, the yearly maps of potential $\mathrm{N}_{2} \mathrm{O}$ emissions were used to derive estimated amounts over the study area, which are associated to corresponding errors computed by taking advantage of the confusion matrix. 


\subsubsection{Errors on $\mathrm{N}_{2} \mathrm{O}$ Emissions Derived from the Confusion Matrix}

The errors on $\mathrm{N}_{2} \mathrm{O}$ emissions are derived from the yearly amounts of $\mathrm{N}_{2} \mathrm{O}$ emissions (Yearly $\mathrm{E}-\mathrm{N}_{2} \mathrm{O}$ ) and the rate of error on emissions, defined as the ratio between the potential emissions of the incorrectly classified pixels $\left(\mathrm{E}-\mathrm{N}_{2} \mathrm{O}_{I C P}\right)$ and those of the correctly classified pixels $\left(\mathrm{E}-\mathrm{N}_{2} \mathrm{O}_{C C P}\right)$ (Equation (2)).

$$
E-\mathrm{N}_{2} \mathrm{O}=\text { Yearly } E-\mathrm{N}_{2} \mathrm{O} \times \frac{E-\mathrm{N}_{2} \mathrm{O}_{I C P}}{E-\mathrm{N}_{2} \mathrm{O}_{C C P}}
$$

The confusion matrix of each yearly land use classification is thus used to estimate the yearly E- $\mathrm{N}_{2} \mathrm{O}$, by considering the correctly and the incorrectly classified pixels and their corresponding mineral nitrogen input. In cases where the pixels are well classified (i.e., the diagonal cases of the confusion matrix), the errors are calculated in a "normal way", considering the number of pixels of the class in question (NP), the mineral nitrogen input (MNI), the emission factor (EF) and the scale factor (SF) (the pixels being 20 by $20 \mathrm{~m}^{2}$ ) (Equation (3)).

$$
E-N_{2} O_{C C P}=\sum_{i=1}^{i=n} N P_{i} \times M N_{i} \times E F \times S F
$$

where $n$ is the number of crop classes.

In cases where the pixels are misclassified, the errors are calculated by taking into account all the possible confusion for a considered culture and summed (Equation (4)). For a given class, the potential emissions of $\mathrm{N}_{2} \mathrm{O}$ of the incorrectly classified pixels are derived from the number of pixels of the confusion class, the absolute difference between the mineral nitrogen input of the reference class and that of the confusion class, the emission factor as well as the scale factor (Equation (5)).

$$
\begin{gathered}
E-N_{2} O_{I C P}=\sum_{i=1}^{i=n} E-N_{2} O_{I C P i} \\
\text { Where } E-N_{2} O_{I C P i}=\sum_{i=1}^{i=m} N P_{m} \times\left|M N I_{m}-M N_{i}\right| \times E F \times S F
\end{gathered}
$$

where $m$ is the number of crop confusion classes.

\subsubsection{Errors on $\mathrm{N}_{2} \mathrm{O}$ Emissions from Emission Factor}

In many cases, the default value of the EF could be adequate; however, many studies suggest that this emission factor could be different according to environmental factors (climate, soil organic $\mathrm{C}$ content, soil texture, drainage and soil $\mathrm{pH}$ ) and to management-related factors ( $\mathrm{N}$ application rate, fertilizer type, type of crop) [3]. The IPCC Guideline proposed for EF a variation range of $0.471-4.71 \%$ that we used to calculate an associated uncertainty to annual potential $\mathrm{N}_{2} \mathrm{O}$ emission was estimated for each year over the study area.

\section{Results}

\subsection{Accuracy of 10 Years of Land Use Classification}

\subsubsection{Overall Performances}

The overall performances of the classifications can be analyzed using indices, such as the kappa (relative difference between the proportion of agreement observed and the proportion of random agreement) which varied between 0.78 and 0.87 , or the overall accuracy (ratio of correctly classified elements to total number of elements examined) which ranged from 0.81 to 0.89 (Table 2). The classifications are characterized by a high level of performances, which appears consistent with previous studies based on comparable methodology [24,25]. The use of multi-temporal high spatial 
resolution images for land use discrimination leads to interesting accuracy, although the results are influenced by the regularity of satellite acquisitions $[26,27]$. The poorest performances are thus associated to the years 2007, 2008 and 2009, being related to the absence of images from the middle of April to the middle of June mainly due to cloudy conditions (see Figure 2). During this critical period, the stem elongation, the flowering, the development of fruit and the ripening are observed for the "winter crops" (i.e., wheat, barley and rapeseed), while the "summer crops" (i.e., corn, sunflower, sorghum and soybean) are sown and show a fast growing season (the inflorescence emergence being observed in June in the early sown plots). Consequently, this period can be considered critical for the study area, with a succession of several phenological stages which steeply affect the dynamic of satellite signals [28,29]. In this context, microwave data acquired by the Sentinel-1 A and B satellites offer an alternative to optical data during cloudy periods. Various studies have thus shown the interest of using such images by combining them with optical images to increase the observation capabilities of the area of interest, or to replace them during critical periods throughout the agricultural season $[25,26,30]$.

Table 2. Overall performances of the yearly classifications (kappa and overall accuracy) for the 2006-2015 period.

\begin{tabular}{ccccccccccc}
\hline Years & $\mathbf{2 0 0 6}$ & $\mathbf{2 0 0 7}$ & $\mathbf{2 0 0 8}$ & $\mathbf{2 0 0 9}$ & $\mathbf{2 0 1 0}$ & $\mathbf{2 0 1 1}$ & $\mathbf{2 0 1 2}$ & $\mathbf{2 0 1 3}$ & $\mathbf{2 0 1 4}$ & $\mathbf{2 0 1 5}$ \\
\hline Kappa & 0.83 & 0.79 & 0.78 & 0.79 & 0.83 & 0.83 & 0.84 & 0.86 & 0.86 & 0.87 \\
Overall Accuracy & 0.85 & 0.82 & 0.81 & 0.82 & 0.85 & 0.85 & 0.86 & 0.88 & 0.88 & 0.89 \\
\hline
\end{tabular}

\subsubsection{Variation of the Inter-Annual Crop Classes Abundance}

The seven considered crop classes occupy, in total, from 44.0 to $54.4 \%$ of the study area (extreme values observed in 2007 and 2013, respectively), and show highly contrasted abundance, depending on the study year (Figure 4). During the study period (2006-2015), wheat occupies more than $18 \%$ of the surface of the study area. The maximum area allocated to wheat is observed in 2013 - the crop was then grown on $25.5 \%$ of the study site. The two other winter crops are less cultivated, as evidence by the maximal abundance of $5.2 \%$ and $2.9 \%$ for barley and rapeseed, respectively. Sunflower and corn are the main summer crops cultivated on the surface, ranging from 11.2 to $16.6 \%$ and 5.1 to $7.6 \%$, respectively. The two last considered crops, sorghum and soybean, never exceed $3 \%$ of the landscape. The two main encountered crops (i.e., wheat and sunflower) are associated with the maximal inter-annual amplitude of abundance variation, showing a difference between the minimal and maximal abundances of 7.5 and $5.4 \%$, respectively. At the opposite, the percent of surface, allocated to rapeseed is almost stable (with a maximal inter-annual range of $1.2 \%$ ).

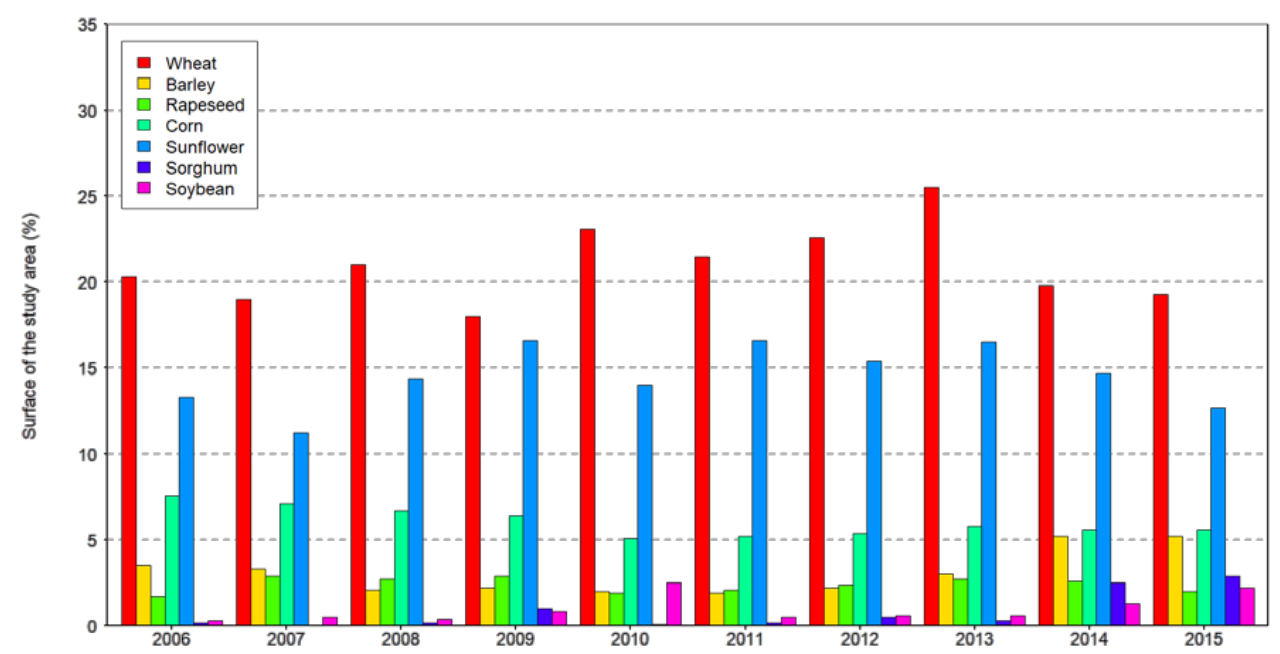

Figure 4. Temporal evolution of the agricultural land use considering 7 classes: wheat, barley, rapeseed, corn, sunflower, sorghum and soybean (expressed in \% of the study area). 


\subsubsection{Main Confusions between the Classes of Interest}

The seven considered crop classes are differently affected by the confusions. Indeed, the mean rate of confusion varies according to the accuracy of each crop class (Figure 5), which itself varies according to its occurrence in the landscape (Figure 4), the quantity or/and the date of images used for classification and the homogeneity of the class.

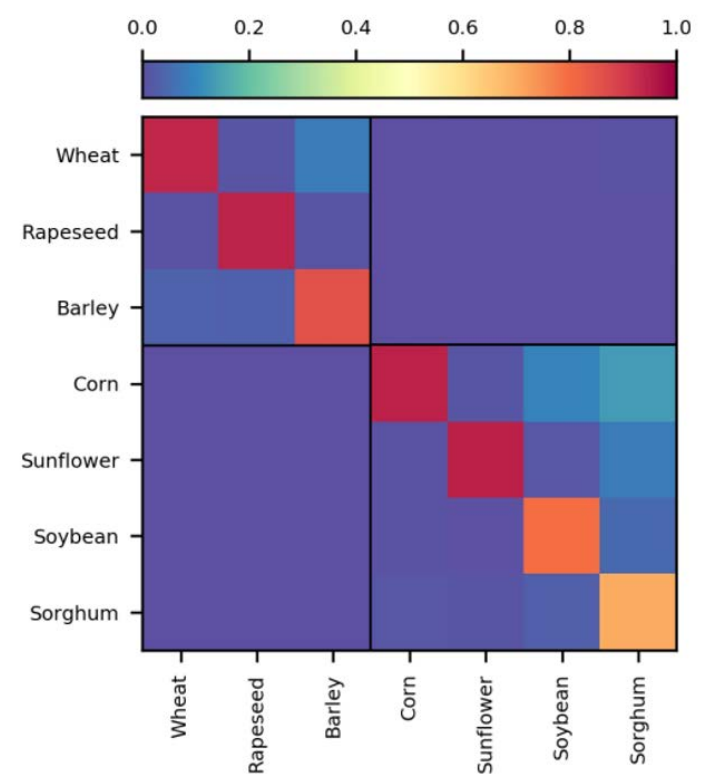

(a)

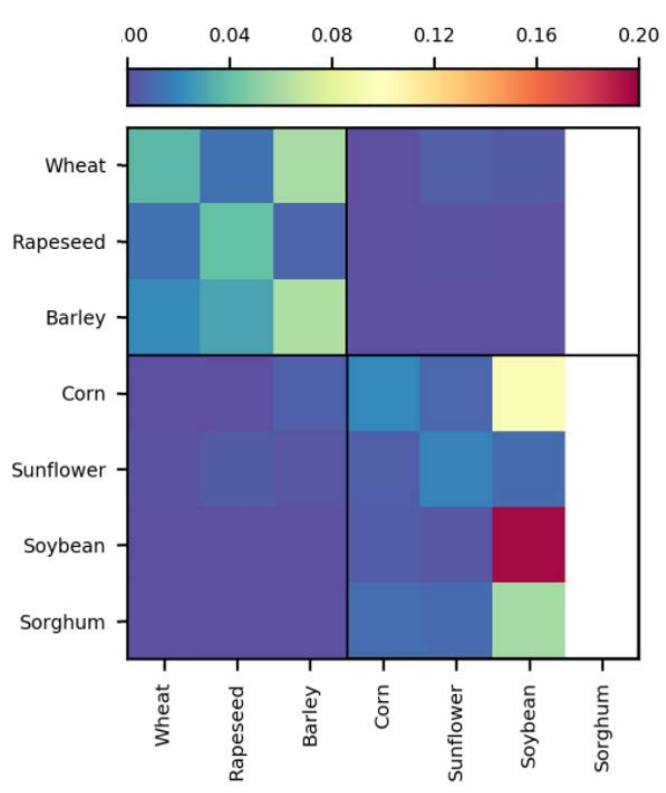

(b)

Figure 5. Mean precision (a) and associated confidence interval (95\%) (b) of the classifications per crop for the 10 years. The red tint indicates the best precision values (a) and the largest confidence interval or largest error $(\mathbf{b})$. The zero confidence values indicate cases where there are not data every year.

Figure 5a shows on the diagonal that winter crops (wheat, rapeseed, barley) reach, over the 10 years, a mean precision varying between 0.85 for barley and 0.94 for rapeseed (or F-Score 0.78 and 0.95 , respectively). The results are very significant, since the confidence interval for winter crops shows an error lower than $5 \%$ (less than 0.05 in the Figure $5 b$ ). In addition, winter crops are mixed together, which is very consistent in terms of agronomy, given the growing seasons of these crops and their comparable structures (particularly for wheat and barley). This is similar for summer crops (maize, sunflower, soybean and sorghum), the mixtures are internal and mainly affect the less-well detected classes. For the main summer crops, the mean accuracy for the 10 years is 0.94 for maize (F-Score $=0.94$ ) and 0.95 for sunflower (F-Score $=0.96$ ). These two classes are overestimated with false positives which can reach $15 \%$ for sorghum class for maize (Figure $5 a$ ) and $10 \%$ for sunflower. For soybean and sorghum, very poorly represented at the study site (Figure 4), the precision varies from 0.61 for sorghum $(\mathrm{F}-\mathrm{Score}=0.48)$ to 0.81 for soybean $(\mathrm{F}-\mathrm{Score}=0.75)$. These classes are under-represented, but the error is less than $8 \%$ (Figure 5b). Sorghum was absent from the study site in 2007 and cannot benefit from an error calculation.

\subsubsection{Consistency of Satellite-Derived Classifications with Departmental Statistics}

The results presented above show that the classifications were associated with high levels of performance, validated on datasets independent of their implementation and associated with a magnitude comparable to different previous studies. The annual crop classifications then allow for a follow-up of the areas allocated to each crop, confirming that wheat and sunflower are the winter and summer crops mainly grown within the study area, respectively. Finally, the confusions between the seven crop classes are mainly observed between these two types of crops (i.e., winter and summer), 
and can be explained by almost synchronous development periods, or even by similarities in the architecture of the plant cover.

The allocated surfaces of the seven considered crop classes derived from the 10 years of land use classification are finally compared to the statistics referenced by the French ministry of agriculture and food [23] (Figure 6). The comparison is provided for two departments, the study site being located straddling on Gers and Haute Garonne (without covering the entire surface area of these departments). The percentages of allocated surface derived from the classification appear consistent with both departments, as confirmed by the high values of the coefficient of determination: $R^{2}{ }_{G E R S}=0.92$ and $\mathrm{R}^{2}$ HAUTE GARONNE $=0.98$. The main differences concern the surfaces allocated to corn (which are underor over-estimated, depending on the department taken as reference), and the two principal crops, sunflower and wheat (which are over-estimated; percentage derived from classifications being closer to data observed in Gers department). Those differences between classification and departmental data are related to both (i) the spatial footprint (with $1275 \mathrm{~km}^{2}$ the study area not covering the entire surface of one of the reference departments) and (ii) the specific location (located in an specific agricultural region where land use and agricultural practices can be different from those observed at the department scale) of the study area.

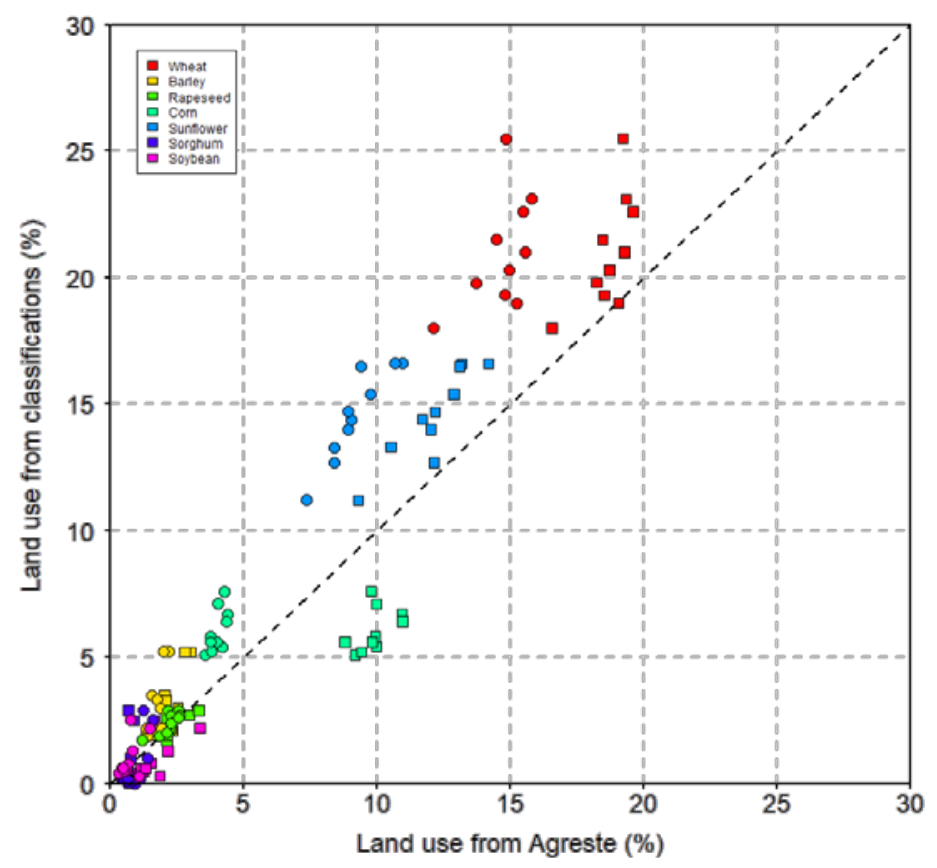

Figure 6. Comparison between the percent of surface allocated to the 7 classes of crop derived from the land use classifications and statistics presented by the French ministry of agriculture and food for the Gers and Haute Garonne counties (squares and circles, respectively).

\subsection{Analysis of the Maps of $\mathrm{N}_{2} \mathrm{O}$ Emissions}

\subsubsection{Analysis of the Yearly Potential Budgets}

Over the study area, the potential yearly budget of $\mathrm{N}_{2} \mathrm{O}$ for the seven crop classes ranges from 97 to 113 tons, extreme values being estimated for the years 2015 and 2013, respectively (Figure 7a). The maps of $\mathrm{N}_{2} \mathrm{O}$ emissions for these two years are presented in Figure $7 \mathrm{~b}, \mathrm{c}$, showing values of emissions per pixel range from 0 to $0.12 \mathrm{~kg}$ (for soybean and corn, respectively) corresponding to a maximum of $2.89 \mathrm{~kg}$ of $\mathrm{N}_{2} \mathrm{O}$ emitted per hectare. The inter-annual variations are explained not only by the total surface allocated to crops but also by the land use changes. Indeed, maximum yearly $\mathrm{N}_{2} \mathrm{O}$ budgets are observed for the years with the highest crop covering of the study area. However, 2015 is the year with the lowest annual $\mathrm{N}_{2} \mathrm{O}$ budget but not with the lowest crop covering. This year, the 
surfaces allocated to wheat are lower (compared to 2013), and two crops associated to lowest $\mathrm{N}_{2} \mathrm{O}$ emissions (i.e., sorghum and soybean) (see Table 1 for their potential $\mathrm{N}_{2} \mathrm{O}$ emissions) present higher abundance rates (Figure 4). Apart the maximum value of 2013, only few variations are observed between the yearly budgets, with a mean close to 100 tons over the study area, and an error lower than 6 tons. Error level variations can vary by a factor of two-that is from 2.6 to 5.4 tons. The maximal value observed during the year 2009 is mainly related to the confusions between the three winter crop classes (i.e., representing almost $44 \%$ the error), with $27 \%$ for the only confusion between wheat and barley crop classes. A significant part of the error is also associated with the confusion between the two summer crops, namely maize and sunflower, reinforced by the difference in mineral nitrogen input observed between these two crops (Table 1). A reduction in crop class confusions would obviously improve firstly classifications and consequently the resulting $\mathrm{N}_{2} \mathrm{O}$ estimates. Nevertheless, the level of uncertainty associated with the emission factor represents a much larger source of variation (or error). Thus, the proposed procedure based on the two extreme values of the emission factor (i.e., $0.471-4.71 \%$ presented in 3.4) leads to estimates ranging from 29 to 34 tons for the minimum bound, and from 290 to 340 tons for the maximum bound. Consequently, compared to this factor of 10, the error deduced from the classifications appears to be very acceptable.

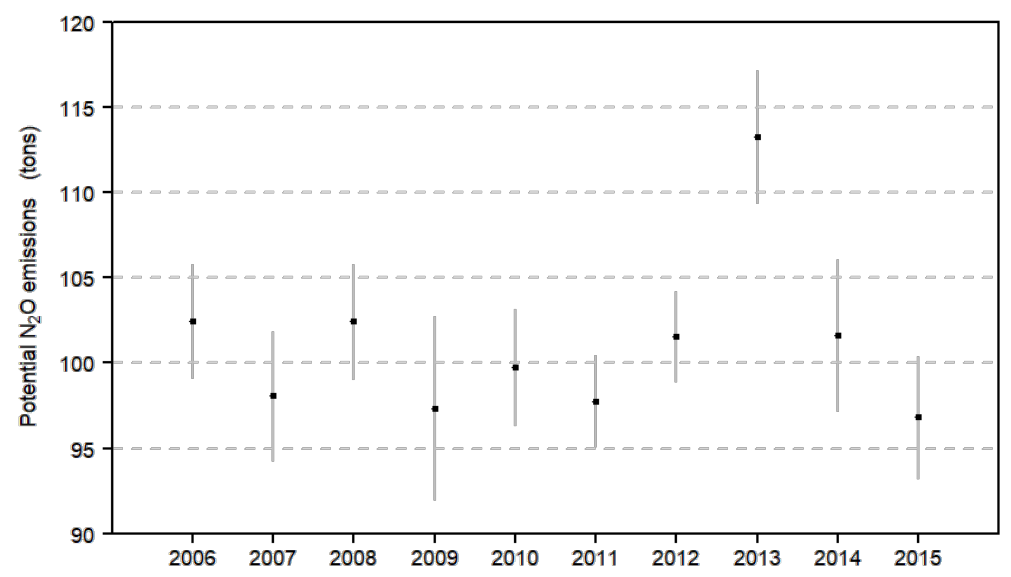

(a)

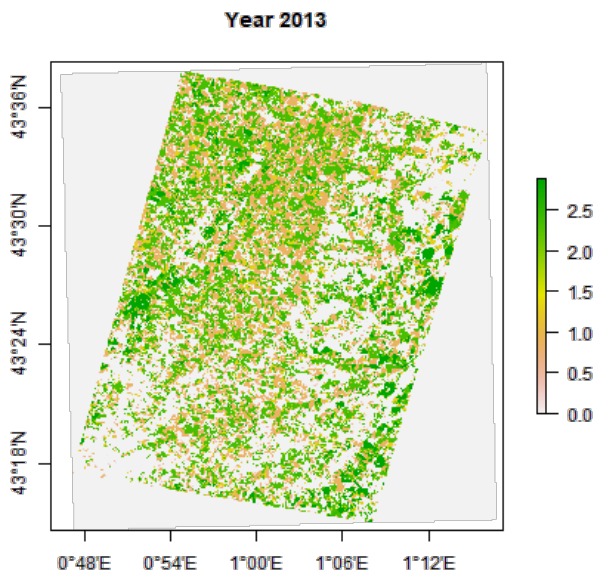

(b)

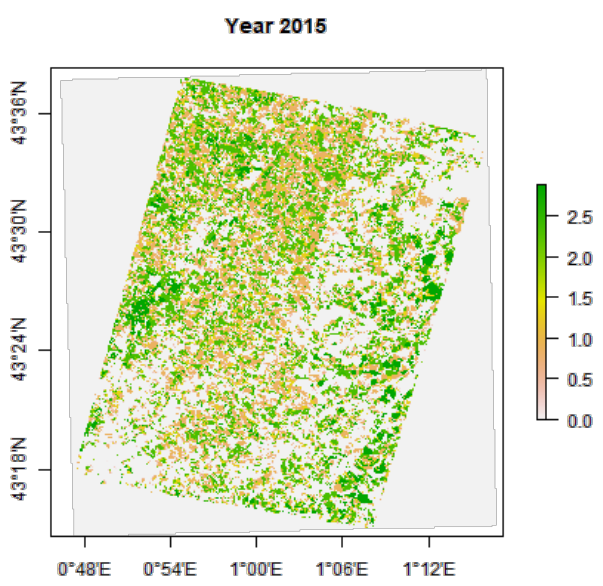

(c)

Figure 7. Time course of the yearly potential budget of $\mathrm{N}_{2} \mathrm{O}$ emissions estimated over the study area (a), together with the maps of potential $\mathrm{N}_{2} \mathrm{O}$ emissions (in $\mathrm{kg}$ of $\mathrm{N}_{2} \mathrm{O}$ ) emitted per pixel derived from the classifications for the years 2013 and 2015 (b,c, respectively). 
The inter-annual variations in $\mathrm{N}_{2} \mathrm{O}$ emissions are illustrated through the difference observed between the two extreme years-that is 2013 and 2015 (Figure 8a). The map gives access to the location of the difference, for which values can either be negative, null, or positive (ranging from -2.89 to $2.89 \mathrm{~kg}$ of $\mathrm{N}_{2} \mathrm{O}$ emitted per hectare), depending on the land use and/or on the crop rotation. Different cases are thus observed, the absence of difference in $\mathrm{N}_{2} \mathrm{O}$ emissions being related to (i) areas not cultivated with one of the seven considered crops (cases not considered in the following) or (ii) areas cultivated with the same crop in both years. This latter case represents $41.2 \%$ of the analyzed agricultural surfaces (Figure 8b), among which the crops of wheat, sunflower and corn are cultivated on the same areas for more than $95 \%$ of the pixels (i.e., respectively, $53.3 \%, 29.9 \%$ and $12.2 \%$ for the three considered crops). Areas associated with negative or positive values correspond to changes in land use, with the following cases: (i) moving from an uncultivated area to a cultivated area with one of the considered $\mathrm{N}_{2} \mathrm{O}$-emitting crops and vice versa (cases abbreviated CO-2013 and CO-2015 for Crop Only in the Figure 8b) or, (ii) rotation with one of the considered crops, characterized by a lower or higher emission rate (only the higher rate are retained in Figure 8b, and abbreviated HE-2013 and HE-2015-HE-2013 corresponding to lower emissions in 2015 and conversely HE-2015 to lower emission in 2013). The explanative contribution of each of these cases in the difference of potential $\mathrm{N}_{2} \mathrm{O}$ emission, observed between the years 2013 and 2015, is finally analyzed by retaining the four last cases (i.e., CO-2013, CO-2015, HE-2013 and HE-2015) and the areas cultivated with the same crop (abbreviated SC) in both years showing similar $\mathrm{N}_{2} \mathrm{O}$ emission are not considered in the following analysis (Figure 8c). Whatever the considered case (CO or HE), potential emissions estimated in 2013 are higher than those obtained in 2015. Rotations with crops characterized by a higher emission rate in 2013 or 2015 (HE-2013 or HE-2015) occupy neighboring surfaces (i.e., 14.4\% and 14.5\%) (Figure 8b), but cumulative $\mathrm{N}_{2} \mathrm{O}$ emissions in these areas are higher in 2013, reaching 12 tons compared with 8.9 tons in 2015. This result is explained by the cultivation of a more $\mathrm{N}_{2} \mathrm{O}$-emitting crop in the rotation (for instances wheat instead of barley, or maize instead of sunflower). Finally, the areas cultivated only in 2013 or in 2015 (CO-2013 or CO-2015) have a difference in surface close to a factor of two (i.e., $9.8 \%$ and $20.1 \%$, Figure $8 b$ ), which explains the higher emissions observed in 2013 with 25 tons, compared to 11.6 tons in 2015 (Figure 8c). In the end, the balance of emissions between the four considered cases is around 16 tons.

\subsubsection{Variation of the Inter-Annual Relative Emission}

The relative emissions associated with each of the studied crops are presented in Figure 9. They are derived from estimates of the potential yearly budget of $\mathrm{N}_{2} \mathrm{O}$ over the period 2006-2015. The relative emissions associated to wheat are the most important regardless of the considered year, with relative values ranging from 48.6 to $60.7 \%$. This crop is mainly grown in the study area (Figure 4 ) and is associated with a high emission rate of $2.34 \mathrm{~kg} \mathrm{~N}_{2} \mathrm{O} . \mathrm{ha}^{-1}$ per year (value just behind that of rapeseed and maize; Table 1). At the opposite side, soybean is characterized by a zero-emission rate, and obviously has zero relative emissions. The values associated with the two other summer crops are particularly interesting. Indeed, the relative emissions associated with maize, between $16.5 \%$ and $24.9 \%$, exceed those associated with sunflower, which vary between $10.7 \%$ and $16.1 \%$. The area allocated to maize cultivation is, however, less important than that allocated to sunflower (between $5.1 \%$ and $7.6 \%$ and between $11.2 \%$ and $16.6 \%$, respectively; Figure 4), but maize is associated with the maximum emission rate, more than three times higher than that of sunflower. The leadership of maize regarding the relative emissions of summer crops tends to decrease, with the area allocated to this crop showing a slight decrease over the decade studied. 


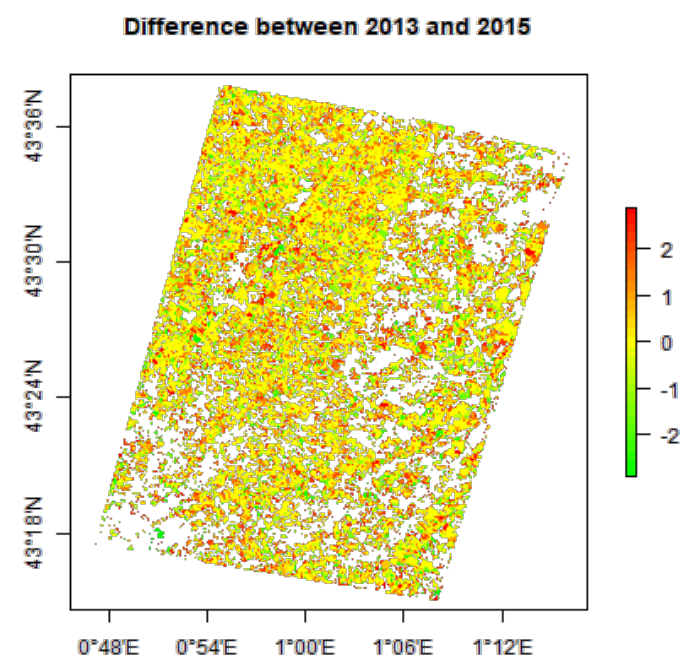

(a)

Details of the cultivated areas

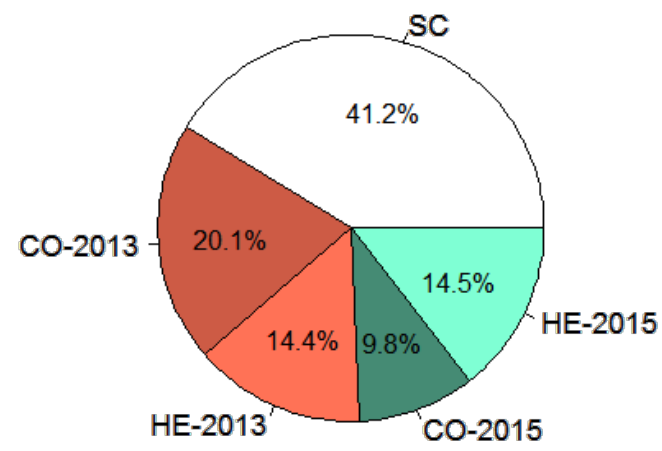

(b)
Emissions of the cultivated areas

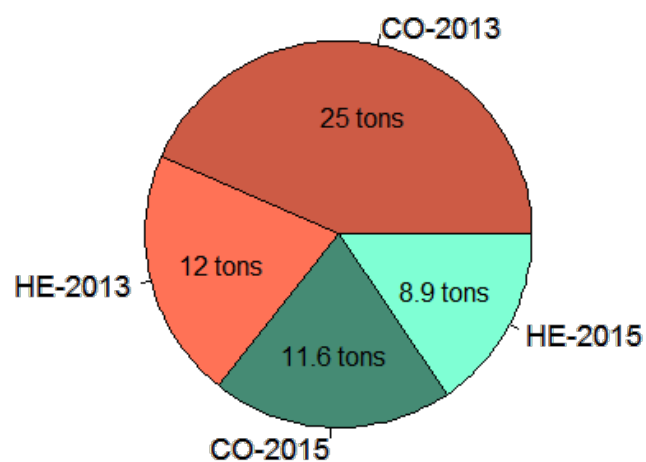

(c)

Figure 8. Inter-annual variations of potential $\mathrm{N}_{2} \mathrm{O}$ emissions (in $\mathrm{kg}$ of $\mathrm{N}_{2} \mathrm{O}$ ) between extreme values emitted for the years 2013 and 2015 (a), together with the allocated surfaces (b) and cumulative $\mathrm{N}_{2} \mathrm{O}$ emissions (c) for the 5 cases, explaining the variations between the two considered years maps (where the abbreviations "SC" "CO" and "HE" correspond to the "Same Crops" cultivated during the two years, "Crops Only" cultivated on a specific year and "Higher Emissions" for the crops cultivated on the specific year).

\subsubsection{Overview of 10 -Years of the Potential $\mathrm{N}_{2} \mathrm{O}$ Budget}

The map showing the balance of potential emissions displays considerable variability at the landscape scale, with values ranging from near zero to $28.9 \mathrm{~kg}$ of $\mathrm{N}_{2} \mathrm{O}$ emitted per hectare (Figure 10a). The spatial patterns observed are closely related to the topography and to the associated cultivated crop species. Areas with high emissions constituting "hot spots" are located in the valleys. They are mainly associated with irrigated corn cultivation. On the other hand, areas with steeper slopes are associated with lower emission levels (around $15 \mathrm{~kg} \mathrm{~N}_{2} \mathrm{O}$ per hectare over the period 2006-2015) and are characterized by rotations of winter and summer crops. The high spatial variability observed in the 10-years $\mathrm{N}_{2} \mathrm{O}$ budget over the study area clearly depends on the land use. The non-zero values 
observed in the maps are analyzed through the histogram presented in Figure 10b, allowing deeper analyzes regarding the encountered agricultural practices.

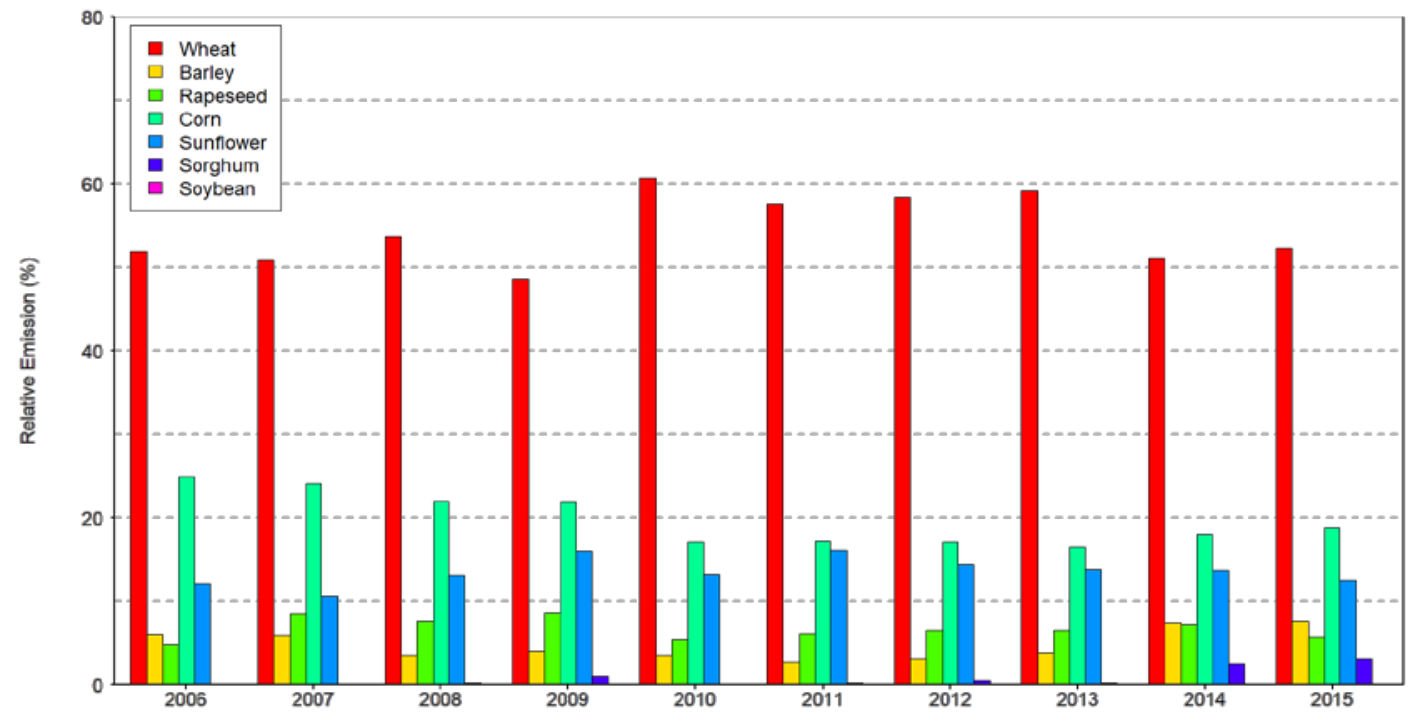

Figure 9. Temporal evolution of the relative emission considering 7 classes: wheat, barley, rapeseed, corn, sunflower, sorghum and soybean (expressed in \% of yearly potential budget of $\mathrm{N} 2 \mathrm{O}$ emissions estimated over the study area).

Cumulated potential $\mathrm{N}_{2} \mathrm{O}$ emissions - 2006 to 2015

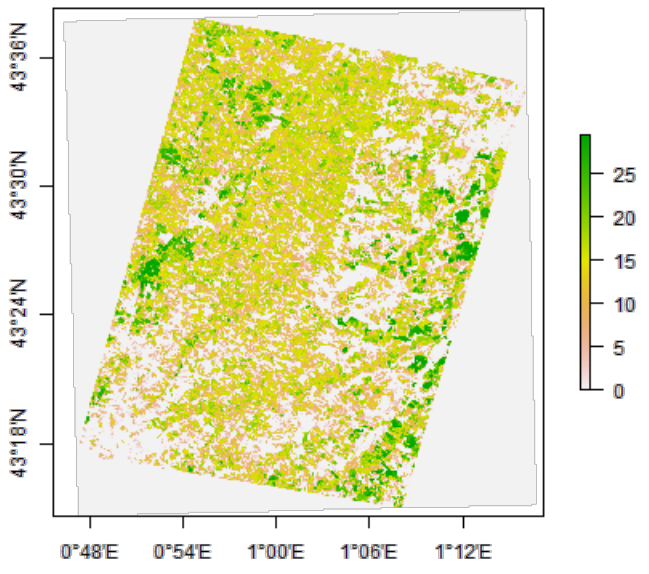

(a)

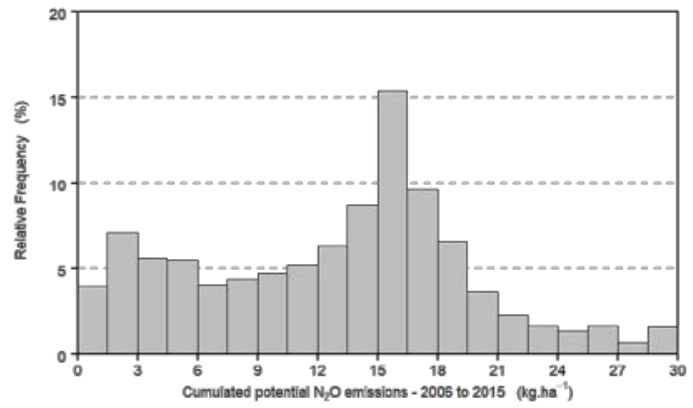

(b)

Figure 10. Ten-years map of the potential $\mathrm{N}_{2} \mathrm{O}$ budget estimated over the study area (a), together with the corresponding histogram derived from the potential emitting areas highlighting the relative occurrence of each potential $\mathrm{N}_{2} \mathrm{O}$ emissions range (b).

Over the study area, $80 \%$ of potential emissions are less than $18 \mathrm{~kg} \mathrm{~N}_{2} \mathrm{O}$ per hectare over the period 2006-2015. With an occurrence exceeding 15\% the range $15-16.5 \mathrm{~kg} \mathrm{~N}_{2} \mathrm{O}$ emitted per hectare for the ten years is the most represented. Such a level of emission is subsequent of a typical rotation observed over the study area, between the main cultivated winter and summer crops that are wheat and sunflower. With $28.9 \mathrm{~kg} \mathrm{~N} 2 \mathrm{O}$ emitted per hectare, less than $2 \%$ of the study area presents the highest possible values and corresponds to ten years of monoculture of maize in the valley. Since maize benefits from the highest $\mathrm{N}$ input, higher $\mathrm{N}_{2} \mathrm{O}$ emissions are estimated on fields where such a crop is cultivated. 
The absence of crop rotation on these plots can be explained by a specific development, either by wet conditions favored near rivers, either notably with access to water resources via infrastructures such as pivots, which cannot be moved to other plots, and which offer maximum profitability with the cultivation of maize during summer. In addition to having a high potential of $\mathrm{N}_{2} \mathrm{O}$ emission, these plots are privileged areas for the resistance of certain pests, such as the maize borer. Conversely, agricultural practices that account for soybeans in rotation have the lowest potential emission levels. However, at the scale of the study site, it represents less than $2.5 \%$ of the territory (maximal value observed in 2010), being most often located on plots offering access to irrigation. In addition to the absence of emission in the proposed inventory approach (because of the non-fertilization associated with the soybean), the crop offers the advantage of setting the atmospheric $\mathrm{N}$, which constitutes an advantage for the next crop.

\section{Discussion}

This method provides access to an inventory of $\mathrm{N}_{2} \mathrm{O}$ emissions, at a fine scale, with an annual update, without a heavy deployment linked to a collection of field measurements. The entire chain can be applied to optical images, and therefore is fully compatible with satellite missions, such as Landsat-8 or Sentinel-2. Moreover, complementary satellite data can be integrated for deriving land-use products at different scales and over various locations, considering, for instance, the microwave data acquired by the Sentinel-1 satellites or other on-going missions [25]. From the land-use products, the yearly potential $\mathrm{N}_{2} \mathrm{O}$ emissions inventory is computable over specific study sites (as presented in this paper), as well as at the country scale (by using for example the recent Theia land-use maps produced over the entire of France, which present crop classes close to the classifications used in the proposed approach [31]). This simple method of implementation has limits, of course, and some points are to be considered for future improvements. Limits mainly concern the lack of considering the influence of the meteorological variables, notably the precipitation (total amount and distribution among the seasons), and of the agricultural practices (tillage, nitrogen input modalities, residues management, irrigation, etc.), that strongly impact the $\mathrm{N}_{2} \mathrm{O}$ production processes [32-37]. Deriving potential $\mathrm{N}_{2} \mathrm{O}$ emissions solely on the basis of $\mathrm{N}$ inputs can lead to an underestimation of the estimated values, particularly in the case of soybean crops. In this case, the estimated potential emissions from our study are zero, while the emissions observed in situ, which depend on other factors, are not [38,39]. Then, the emission factor value and values of mineral nitrogen inputs used are subject to criticism. Moreover, in most managed soils, an increase in available $\mathrm{N}$ not only depends on synthetic $\mathrm{N}$ fertilizer input but also on organic $\mathrm{N}$ fertilizer application and on the soil potential mineralization, the latter depending on nitrogen and carbon content in crop residues (below-ground and above-ground) and on soil organic matter content [40,41].

This inventory method could be improved by taking into account the total available nitrogen in benefiting from the recent or in progress development of new remote sensing products, such as mapping of crop yield (allowing for estimating $\mathrm{N}$ in crop residues, [42]) and mapping of clay and soil organic matter content (allowing for estimating "background" soil N organic content, [43]). Moreover the consideration of such a key drivers' effect, easily accessible on a larger area than plot scale, has been analyzed and formalized in an empirical model developed in southwestern France [44] that could be coupled with remote sensing products (i.e., land use maps and vegetation index derived from optical images) and applied in a generic way on large area. However, access to specialized organic $\mathrm{N}$ fertilizer application information remains challenging. Other improvements could be enhanced to our inventory method by integrating the crop rotation aspect, with variable values of mineral nitrogen inputs depending on the previously cultivated crop. With this same idea, a finer mapping of the succession of surface states and implemented cultural practices would refine estimates of potential emissions of $\mathrm{N}_{2} \mathrm{O}$. 


\section{Conclusions}

This paper presents a useful methodology to access yearly potential $\mathrm{N}_{2} \mathrm{O}$ emissions inventories over agricultural landscape at a fine spatial scale, based on optical satellite images and a theoretical amount of mineral inputs of N. The proposed approach provides a simple processing chain fully that is reproducible when the area of interest has information on land use or satellite imagery. The main results of this work concern the accurate performances associated with the land use classification (with kappa superior to 0.78 ), which allows for the yearly estimates of $\mathrm{N}_{2} \mathrm{O}$ emissions at a spatial resolution of 20 by $20 \mathrm{~m}^{2}$ and analyzing the effect of crop rotation choices and their distribution in the territory landscape on the latter. The yearly potential budget of $\mathrm{N}_{2} \mathrm{O}$ emissions derived over the study area, showed values ranging from 97 to 113 tons for the 2006-2015 period with a relative error of less than $5.5 \%$. The mapping of 10 years of potential $\mathrm{N}_{2} \mathrm{O}$ emissions shows strong contrasts, with minimal budgets when soybean is regularly cultivated in the crop rotation. At the opposite side, the maximum values are associated to the monoculture maize ( $28.9 \mathrm{~kg}$ of $\mathrm{N}_{2} \mathrm{O}$ emitted per hectare). In this range of values, the mainly observed rotation with alternating wheat and sunflower crops reaches potential emissions close to $16 \mathrm{~kg}$ of $\mathrm{N}_{2} \mathrm{O}$ emitted per hectare. This simple approach clearly highlights the effect of crop rotation type, "economically" chosen and/or constrained by the topography, on the potential annual $\mathrm{N}_{2} \mathrm{O}$ emissions at a territory scale. In this study, potential $\mathrm{N}_{2} \mathrm{O}$ emissions are estimated by considering an inventory aspect, which is a first step that could be completed by the identification of the main spatializable drivers of the flux dynamics, in order to identify mitigation strategies.

Author Contributions: Conceptualization, R.F., C.M.S. and T.T.; methodology, R.F., C.M.S. and T.T.; formal analysis, R.F., C.M.S. and T.T.; writing-original draft preparation, review and editing, R.F., C.M.S. and T.T. All authors have read and agreed to the published version of the manuscript.

Funding: This research received no external funding.

Acknowledgments: Remote sensing data acquisition was mainly funded by the Institut National des Sciences de l'Univers (INSU) through the South-West Regional Spatial Observatory (OSR SW). Staff are funded and supported by the Observatory Midi-Pyrenean, the University Paul Sabatier of Toulouse, CNRS (Centre National de la Recherche Scientifique), CNES (Centre National d'Etude Spatial), INRAe (Institut national de recherche pour l'agriculture, l'alimentation et l'environnement) and IRD (Institut de Recherche pour le Développement).

Conflicts of Interest: The authors declare no conflict of interest.

\section{References}

1. Montzka, S.A.; Dlugokencky, E.J.; Butler, J.H. Non- $\mathrm{CO}_{2}$ greenhouse gases and climate change. Nat. Cell Biol. 2011, 476, 43-50. [CrossRef] [PubMed]

2. Davidson, E.A.; Kanter, D. Inventories and scenarios of nitrous oxide emissions. Environ. Res. Lett. 2014, 9, 105012. [CrossRef]

3. Kristell, H.; Hiroko, A.; Martial, B.; Ngonidzashe, C.; del Agustin, P.; Åsa, K.; James, D.M.; Stephen, M.; Kristiina, R.; van der Weerden, T.J. $\mathrm{N}_{2} \mathrm{O}$ Emissions from Managed Soils, and $\mathrm{CO}_{2}$ Emissions from Lime and Urea Application. In IPCC 2019, 2019 Refinement to the 2006 IPCC Guidelines for National Greenhouse Gas Inventories; IPCC: Geneva, Switzerland, 2019.

4. Viard, A.; Hénault, C.; Rochette, P.; Kuikman, P.; Flenet, F.; Cellier, P. Le protoxyde d'azote $\left(\mathrm{N}_{2} \mathrm{O}\right)$, puissant gaz à effet de serre émis par les sols agricoles: Méthodes d'inventaire et leviers de réduction. Oléagineux Corps Gras Lipides 2013, 20, 108-118. [CrossRef]

5. Wysocka-Czubaszek, A.; Czubaszek, R.; Roj-Rojewski, S.; Banaszuk, P. Methane and Nitrous Oxide Emissions from Agriculture on a Regional Scale. J. Ecol. Eng. 2018, 19, 206-217. [CrossRef]

6. Prather, M.J.; Holmes, C.D.; Hsu, J. Reactive greenhouse gas scenarios: Systematic exploration of uncertainties and the role of atmospheric chemistry. Geophys. Res. Lett. 2012, 39, 09803. [CrossRef]

7. Xiang, B.; Miller, S.M.; Kort, E.A.; Santoni, G.W.; Daube, B.C.; Commane, R.; Angevine, W.M.; Ryerson, T.B.; Trainer, M.K.; Andrews, A.E.; et al. Nitrous oxide $\left(\mathrm{N}_{2} \mathrm{O}\right)$ emissions from California based on 2010 CalNex airborne measurements. J. Geophys. Res. Atmos. 2013, 118, 2809-2820. [CrossRef]

8. Del Grosso, S.J.; Wirth, T.; Ogle, S.M.; Parton, W.J. Estimating Agricultural Nitrous Oxide Emissions. EOS Trans. Am. Geophys. Union. 2008, 89, 529. [CrossRef] 
9. Lugato, E.; Zuliani, M.; Alberti, G.; Vedove, G.D.; Gioli, B.; Miglietta, F.; Peressotti, A. Application of DNDC biogeochemistry model to estimate greenhouse gas emissions from Italian agricultural areas at high spatial resolution. Agric. Ecosyst. Environ. 2010, 139, 546-556. [CrossRef]

10. Olander, L.P.; Haugen-Kozyra, K. Using Biogeochemical Process to Models to Quantify Greenhouse Gas Mitigation from Agricultural Management Projects; Technical Working Group on Agricultural Greenhouse Gases (T-AGG) Supplemental Report; Duke University: Durham, NC, USA, 2011.

11. US EPA 2014. Inventory of U.S. Greenhouse Gas Emissions and Sinks: 1990-2012 Report EPA 430-R-14-003; U.S. Environmental Protection Agency: Washington, DC, USA, 2014.

12. Kasper, M.; Foldal, C.; Kitzler, B.; Haas, E.; Strauss, P.; Eder, A.; Zechmeister-Boltenstern, S.; Amon, B. N $2 \mathrm{O}$ emissions and $\mathrm{NO}_{3}-$ leaching from two contrasting regions in Austria and influence of soil, crops and climate: A modelling approach. Nutr. Cycl. Agroecosyst. 2018, 113, 95-111. [CrossRef]

13. Gaillardet, J.; Braud, I.; Hankard, F.; Anquetin, S.; Bour, O.; Dorfliger, N.; de Dreuzy, J.R.; Galle, S.; Galy, C.; Gogo, S.; et al. OZCAR: The French Networkof Critical Zone Observatories. Vadose Zone J. 2018, 17, 1-24. [CrossRef]

14. Sicre, C.M.; Baup, F.; Fieuzal, R. Determination of the crop row orientations from Formosat-2 multi-temporal and panchromatic images. ISPRS J. Photogramm. Remote Sens. 2014, 94, 127-142. [CrossRef]

15. Arnaud, M.; Leroy, M. SPOT 4: A new generation of SPOT satellites. ISPRS J. Photogramm. Remote Sens. 1991, 46, 205-215. [CrossRef]

16. Roy, D.P.; Wulder, M.A.; Loveland, T.R.; Woodcock, C.E.; Allen, R.G.; Anderson, M.C.; Helder, D.; Irons, J.R.; Johnson, D.M.; Kennedy, R.S.H.; et al. Landsat-8: Science and product vision for terrestrial global change research. Remote Sens. Environ. 2014, 145, 154-172. [CrossRef]

17. Hagolle, O.; Huc, M.; Pascual, D.V.; Dedieu, G. A Multi-Temporal and Multi-Spectral Method to Estimate Aerosol Optical Thickness over Land, for the Atmospheric Correction of FormoSat-2, LandSat, VEN $\mu$ S and Sentinel-2 Images. Remote Sens. 2015, 7, 2668-2691. [CrossRef]

18. Breiman, L. Random forests. Mach. Learn. 2001, 45, 5-32. [CrossRef]

19. Gislason, P.O.; Benediktsson, J.A.; Sveinsson, J.R. Random Forests for land cover classification. Pattern Recognit. Lett. 2006, 27, 294-300. [CrossRef]

20. Loosvelt, L.; Peters, J.; Skriver, H.; Lievens, H.; Van Coillie, F.M.; De Baets, B.; Verhoest, N.E. Random Forests as a tool for estimating uncertainty at pixel-level in SAR image classification. Int. J. Appl. Earth Obs. Geoinf. 2012, 19, 173-184. [CrossRef]

21. Van Rijsbergen, C.J. Information Retrieval; Butterworths: London, UK, 1979.

22. Powers, D.M.W. Evaluation: From Precision, Recall and F-Factor to ROC, Informedness, Markedness \& Correlation. J. Mach. Learn. Technol. 2011, 2, 37-63.

23. Agreste-La Statistique, L'évaluation et la Prospective Agricole. Ministère de L'agriculture et de L'alimentation. Available online: https://agreste.agriculture.gouv.fr/agreste-web/ (accessed on 2 November 2020).

24. Inglada, J.; Arias, M.; Tardy, B.; Hagolle, O.; Valero, S.; Morin, D.; Dedieu, G.; Sepulcre, G.; Bontemps, S.; Defourny, P.; et al. Assessment of an Operational System for Crop Type Map Production Using High Temporal and Spatial Resolution Satellite Optical Imagery. Remote Sens. 2015, 7, 12356-12379. [CrossRef]

25. Sicre, C.M.; Fieuzal, R.; Frappart, F. Contribution of multispectral (optical and radar) satellite images to the classification of agricultural surfaces. Int. J. Appl. Earth Obs. Geoinf. 2020, 84, 101972. [CrossRef]

26. Inglada, J.; Vincent, A.; Arias, M.; Marais-Sicre, C. Improved Early Crop Type Identification by Joint Use of High Temporal Resolution SAR And Optical Image Time Series. Remote Sens. 2016, 8, 362. [CrossRef]

27. Marais, S.C.; Inglada, J.; Fieuzal, R.; Baup, F.; Valero, S.; Cros, J.; Huc, M.; Demarez, V. Early detection of summer crops using high spatio-temporal resolution optical images time series. Remote Sens. 2016, 8, 591. [CrossRef]

28. Fieuzal, R.; Baup, F.; Marais-Sicre, C. Monitoring Wheat and Rapeseed by Using Synchronous Optical and Radar Satellite Data-From Temporal Signatures to Crop Parameters Estimation. Adv. Remote Sens. 2013, 2, 162-180. [CrossRef]

29. Fieuzal, R.; Baup, F. Estimation of leaf area index and crop height of sunflowers using multi-temporal optical and SAR satellite data. Int. J. Remote Sens. 2016, 37, 2780-2809. [CrossRef] 
30. McNairn, H.; Champagne, C.; Shang, J.; Holmstrom, D.; Reichert, G. Integration of optical and Synthetic Aperture Radar (SAR) imagery for delivering operational annual crop inventories. ISPRS J. Photogramm. Remote Sens. 2009, 64, 434-449. [CrossRef]

31. Inglada, J.; Vincent, A.; Arias, M.; Tardy, B.; Morin, D.; Rodes, I. Operational High Resolution Land Cover Map Production at the Country Scale Using Satellite Image Time Series. Remote Sens. 2017, 9, 95. [CrossRef]

32. Zimmermann, J.; Carolan, R.; Forrestal, P.; Harty, M.; Lanigan, G.; Richards, K.; Roche, L.; Whitfield, M.; Jones, M. Assessing the performance of three frequently used biogeochemical models when simulating $\mathrm{N}_{2} \mathrm{O}$ emissions from a range of soil types and fertiliser treatments. Geoderma 2018, 331, 53-69. [CrossRef]

33. Yang, T.; Li, F.; Zhou, X.; Xu, C.; Feng, J.; Fang, F. Impact of nitrogen fertilizer, greenhouse, and crop species on yield-scaled nitrous oxide emission from vegetable crops: A meta-analysis. Ecol. Indic. 2019, 105, 717-726. [CrossRef]

34. Ball, B.C.; Scott, A.; Parker, J.P. Field $\mathrm{N}_{2} \mathrm{O}, \mathrm{CO}_{2}$ and $\mathrm{CH} 4$ fluxes in relation to tillage, compaction and soil quality in Scotland. Soil Tillage Res. 1999, 53, 29-39. [CrossRef]

35. Franco-Luesma, S.; Cavero, J.; Plaza-Bonilla, D.; Cantero-Martínez, C.; Tortosa, G.; Bedmar, E.J.; Álvaro-Fuentes, J. Irrigation and tillage effects on soil nitrous oxide emissions in maize monoculture. Agron. J. 2020, 112, 56-71. [CrossRef]

36. Sanz-Cobena, A.; Lassaletta, L.; Aguilera, E.; Del Prado, A.; Garnier, J.; Billen, G.; Iglesias, A.; Sánchez-Jimeno, B.; Guardia, G.; Abalos, D.; et al. Strategies for greenhouse gas emissions mitigation in Mediterranean agriculture: A review. Agric. Ecosyst. Environ. 2017, 238, 5-24. [CrossRef]

37. Lognoul, M.; Theodorakopoulos, N.; Hiel, M.-P.; Regaert, D.; Broux, F.; Heinesch, B.; Bodson, B.; Vandenbol, M.; Aubinet, M. Impact of tillage on greenhouse gas emissions by an agricultural crop and dynamics of $\mathrm{N}_{2} \mathrm{O}$ fluxes: Insights from automated closed chamber measurements. Soil Tillage Res. 2017, 167, 80-89. [CrossRef]

38. Sánchez, C.; Minamisawa, K. Nitrogen Cycling in Soybean Rhizosphere: Sources and Sinks of Nitrous Oxide $\left(\mathrm{N}_{2} \mathrm{O}\right)$. Front. Microbiol. 2019, 10, 1943. [CrossRef] [PubMed]

39. Yang, L.; Cai, Z. The effect of growing soybean (Glycine max. L.) on $\mathrm{N}_{2} \mathrm{O}$ emission from soil. Soil Biol. Biochem. 2005, 37, 1205-1209. [CrossRef]

40. Senbayram, M.; Chen, R.; Budai, A.; Bakken, L.; Dittert, $\mathrm{K} . \mathrm{N}_{2} \mathrm{O}$ emission and the $\mathrm{N}_{2} \mathrm{O} /\left(\mathrm{N}_{2} \mathrm{O}+\mathrm{N}_{2}\right)$ product ratio of denitrification as controlled by available carbon substrates and nitrate concentrations. Agric. Ecosyst. Environ. 2012, 147, 4-12. [CrossRef]

41. Mary, B.; Clivot, H.; Blaszczyk, N.; Labreuche, J.; Ferchaud, F. Soil carbon storage and mineralization rates are affected by carbon inputs rather than physical disturbance: Evidence from a 47-year tillage experiment. Agric. Ecosyst. Environ. 2020, 299, 106972. [CrossRef]

42. Pique, G.; Fieuzal, R.; Al Bitar, A.; Veloso, A.; Tallec, T.; Brut, A.; Ferlicoq, M.; Zawilski, B.; Dejoux, J.-F.; Gibrin, H.; et al. Estimation of daily $\mathrm{CO}_{2}$ fluxes and of the components of the carbon budget for winter wheat by the assimilation of Sentinel 2-like remote sensing data into a crop model. Geoderma 2020, 376, 114428. [CrossRef]

43. Vaudour, E.; Gomez, C.; Fouad, Y.; Lagacherie, P. Sentinel-2 image capacities to predict common topsoil properties of temperate and Mediterranean agroecosystems. Remote Sens. Environ. 2019, 223, 21-33. [CrossRef]

44. Bigaignon, L.; Le Dantec, V.; Delon, C.; Brut, A.; Ceschia, E.; Mordelet, P.; Zawilski, B.; Granouillac, F.; Claverie, N.; Fieuzal, R.; et al. $\mathrm{N}_{2} \mathrm{O}$ budget from 10 site-years measurement on two crop fields in southwestern France: Impact of agricultural practices and calculation methodology. Agric. For. Manag. 2020. under review.

Publisher's Note: MDPI stays neutral with regard to jurisdictional claims in published maps and institutional affiliations.

(C) 2020 by the authors. Licensee MDPI, Basel, Switzerland. This article is an open access article distributed under the terms and conditions of the Creative Commons Attribution (CC BY) license (http://creativecommons.org/licenses/by/4.0/). 